\title{
Anaesthesia of Common Carp (Cyprinus carpio L.) with 2-phenoxyethanol: Acute Toxicity and Effects on Biochemical Blood Profile
}

\author{
J. VELÍŠEK ${ }^{1}, Z$. SVOBODOVÁ ${ }^{2,3}$ \\ ${ }^{1}$ University of South Bohemia, Faculty of Agriculture, České Budějovice \\ ${ }^{2}$ University of South Bohemia, Research Institute of Fish Culture and Hydrobiology, Vodňany \\ ${ }^{3}$ University of Veterinary and Pharmaceutical Science, Brno \\ Received December 12, 2003 \\ Accepted June 17, 2004
}

\begin{abstract}
Velíšek J., Z. Svobodová: Anaesthesia of Common Carp (Cyprinus carpio L.) with 2-phenoxyethanol: Acute Toxicity and Effects on Biochemical Blood Profile. Acta Vet. Brno 2004, 73: 247-252.

The aim of the present study was to assess acute toxicity of the 2-phenoxyethanol anaesthetic in carp, and assess changes in their tissues using the biochemical blood profiles. Acute toxicity values of 2-phenoxyethanol in the carp fry determined by the OECD 203 method "Acute toxicity test in fish" were 10minLC50 $0.39 ; 10$ minLC0.1 $0.30 ; 10 \operatorname{minLC} 99.90 .50 \mathrm{ml} \cdot 1^{-1}$, 96hLC50 0.17 ; 96hLC0.1 0.13; and 96hLC99.9 $0.26 \mathrm{ml}^{-1} \mathrm{l}^{-1}$

A biochemical analysis of blood plasma (VETTEST 8008 analyser, Medisoft Co.) was used to determine changes in the biochemical profile of blood in carp stockfish due to anaesthesia by 2-phenoxyethanol. The analyses were made immediately prior the anaesthesia and after a $10 \mathrm{~min}$ and $24 \mathrm{~h}$ exposure to the anaesthetic at a concentration of $0.30 \mathrm{ml} \cdot \mathrm{l}^{-1}$. A total of 30 two-year-old carp were examined. A significant increase in blood plasma alanine aminotransferase (ALT) levels from $0.15 \mu \mathrm{kat} \cdot \mathrm{l}^{-1}$ to $0.35 \mu \mathrm{kat} \cdot \mathrm{l}^{-1}(P<0.05)$ was found $24 \mathrm{~h}$ after anaesthesia. The other indices monitored [cortisol, glucose (GLU), total proteins (TP), triglycerides (TRIG), ammonia (NH3), alkaline phosphatase (ALP), aspartate aminotransferase (AST) and creatine kinase (CK)] showed no significant differences among the groups of fish examined.

The results showed that 2-phenoxyethanol at a concentration of $0.30 \mathrm{ml} \cdot \mathrm{l}^{-1}$ is not completely safe for carp fry and two-year old carp. In view of different sensitivities in different age group mentioned above, the authors assume that concentration will be safe for broodstock carp.
\end{abstract}

LC50, blood plasma, cortisol, glucose, proteins, enzymes

The anaesthetic 2-phenoxyethanol is used not only for short-term immobilization of fish before artificial propagation, but also whenever fish is handled outside water, e.g. during veterinary interventions. The generally recommended concentration is $0.20 \mathrm{ml} \cdot \mathrm{l}^{-1}$ water bath. For large brood fish (e.g. wels), the concentration of $0.30 \mathrm{ml} \cdot \mathrm{l}^{-1}$ water bath is recommended. At the recommended concentrations, anaesthesia takes effect within 5 - 10 min. When the fish are transferred to clean water, their physiological reflexes are restored in $10 \mathrm{~min}$.

Modern anaesthetics are expected to be highly soluble in water, quick to take effect, safe for both fish and humans, with wide margins of safety, offer the possibility to increase the degree of anaesthesia as required and to spontaneously recover from anaesthesia. Also, modern anaesthetics should leave no residues in fish (Brožová and Svobodová 1986; Brown 1988; Ross and Ross 1999). The effect of 2-phenoxyethanol on carp was studied by Adámek et al. (1993).

At present, effects on 2-phenoxyethanol on commercially produced fish are studied in a project regarding the application of principles of pharmacovigilancy in aquaculture in the Czech Republic. In the first stage of the project, effects of 2-phenoxyethanol on rainbow

Address for correspondence:

Ing. Josef Velíšek

University of South Bohemia, Faculty of Agriculture

Department of Anatomy and Physiology of Farm Animals

Studentská 13

37005 České Budějovice

Phone: +420732155886

Fax: + 42038777262

E-mail: velisek.j@centrum.cz

http://www.vfu.cz/acta-vet/actavet.htm 
trout were studied (Velíšek and Svobodová 2004). The aim of the present study was to assess acute toxicity of 2-phenoxyethanol in anaesthetized carp and changes in their tissues using biochemical blood profile values.

\section{Materials and Methods}

2-phenoxyethanol characteristics

The active substance of 2-phenoxyethanol is ethylene glycol monophenyl ether. Its summary formula is $\mathrm{C}_{8} \mathrm{H}_{10} \mathrm{O}_{2}$, the molar weight $138.17 \mathrm{~g} \cdot \mathrm{l}^{-1}$, density $1.107-1.108$, peroxide content less than $0.005 \%$ and the boiling temperature is $245^{\circ} \mathrm{C}$. The anaesthetic is slightly soluble in water $\left(26.7 \mathrm{~g} \cdot \mathrm{l}^{-1}\right)$ but readily soluble in ethanol. The anaesthetic affects fish through skin and gills.

The anaesthetic is marketed by MERCK - Schucherd, 85662 Hohenbrunn, Germany in 2.5 and 1 litre packages, or in other volumes on request.

Acute toxicity test

Carp fry (mirror carp M 72) of $21.9 \mathrm{~g}$ mean body mass (15.7 - $28.1 \mathrm{~g}$ ) and $11.1 \mathrm{~cm}$ mean standard length (10.2 $-12 \mathrm{~cm}$ ), Fulton index $1.6(1.5-1.7)$, were used to ascertain LC50 of 2-phenoxyethanol after $96 \mathrm{~h}$ and $10 \mathrm{~min}$ exposures to the anaesthetic.

In the test to establish the 96-hour LC50 of 2-phenoxyethanol, fish were exposed to 2-phenoxyethanol concentrations of $0.10 ; 0.12 ; 0.15 ; 0.18 ; 0.20 ; 0.25 ; 0.30$; and $0.35 \mathrm{ml} \cdot 1^{-1}$ in diluting water $(\mathrm{pH} 7.81$; acid neutralization capacity - $\mathrm{ANC}_{4.5} 1.15 \mathrm{mmol} \cdot \mathrm{l}^{-1}$; total ammonia $0.04 \mathrm{mg} \cdot \mathrm{l}^{-1} ; \mathrm{NO}_{3}^{-} 11.5 \mathrm{mg} \cdot \mathrm{l}^{-1} ; \mathrm{NO}_{2}^{-} 0.005 \mathrm{mg} \cdot \mathrm{l}^{-1}$; $\mathrm{PO}_{3}^{-} 0.01 \mathrm{mg} \cdot \mathrm{l}^{-1}$; chemical oxygen demand - CODMn $1.6 \mathrm{mg} \cdot \mathrm{l}^{-1}$ ), and the controls were exposed to diluting water without the substance tested. Ten carp fry were used per every concentration and for a control group; a total of 90 carp fry were used. The state and behaviour of the fish, as well as temperature, $\mathrm{pH}$ and oxygen saturation of water at each concentration and in the control aquarium were checked throughout the test. Medium lethal concentrations of 2-phenoxyethanol for 96 hour exposure (96hLC50) as well as 96hLC0.1 and 96hLC99.9 were computed from those values using the probit analysis (EKO-TOX 5.1 software).

In the test to determine the LC50 in a 10 min exposure, concentrations of $0.30 ; 0.35 ; 0.40 ; 0.50 \mathrm{ml} \cdot \mathrm{l}^{-1}$ 2-phenoxyethanol dissolved in water were used. A total of 40 carp fry were used, ten per each concentration. The diluting water had the same characteristics as water used in the 96hLC assay. Changes in the physiological status of the fish, the number of dead fish and the recovery time after the fish were transferred to clean water were recorded. Medium lethal concentrations for the $10 \mathrm{~min}$ exposure (10minLC50, 10minLC0.1 and 10minLC99.9) were computed from the values using the probit analysis (EKO-TOX 5.1 software).

The following four stages were observed in the changing physiological status of the anaesthetized fish (Thienpoint and Niemegeers 1965):

1. an increase and a subsequent decrease in the frequency of respiratory movements, a partial inhibition of reactions to external stimuli

2. loss of balance, very slow respiratory movements, fish still react to strong stimuli

3. total loss of reflexes, fish lay on bottom of the tank, irregular respiration, fish do not react to handling

4. respiratory movements cease completely, fish die if left in the bath.

Biochemical examination of blood plasma

Carp stockfish (mirror carp M 72) of $367 \mathrm{~g}$ mean body mass (227 - $507 \mathrm{~g}$ ) and $25.5 \mathrm{~cm}$ mean standard length (19 $-32 \mathrm{~cm}$ ), Fulton index $2.21(1.58-3.30)$, were used for the determination of biochemical profile of blood plasma. A total of 30 carp were used in the examinations before anaesthesia (10 carp), after 10-min exposure to the anaesthetic ( 10 specimens) and $24 \mathrm{~h}$ exposure to anaesthetic ( 10 specimens).

The anaesthetic was administered at the concentration of $0.30 \mathrm{ml} \cdot 1^{-1} 2$-phenoxyethanol for $10 \mathrm{~min}$. The blood was collected by a heparinized needle from the heart (after the fish were stunned by a blow to the head). Aqueous solution of heparin sodium salt was used for blood stabilization (Heparin SPOFA inj.) at a concentration of 5000 i.u. sodium salt heparin/ml. To stabilize $1 \mathrm{ml}$ blood, $0.01 \mathrm{ml}$ of aqueous solution of heparin was used (S v obod ová et al. 1986).

Blood samples were centrifuged in a cooled centrifuge $\left(4^{\circ} \mathrm{C}, 837 \times \mathrm{g}\right)$. The biochemical indices determined in blood plasma included cortisol, glucose (GLU), total proteins (TP), ammonia $\left(\mathrm{NH}_{3}\right.$ ), triglycerides (TRIG), aspartate aminotransferase (AST), alanine aminotranspherase (ALT), alkaline phosphatase (ALP), and creatine kinase (CK). For the creatine kinase determination, blood plasma was diluted at the 1:12 ratio with physiological saline. For the biochemical analysis of blood plasma, VETTEST 8008 analyser (IDEXX Laboratories Inc. U.S.A.) was used. The analyzer utilizes dry chemical technology and a colorimetric reaction. The sample analysis was performed on selective testing discs (Multi-layer film slides, Kodak) by means of laser reading the bar codes.

For the statistical test, the analysis of variance was used (ANOVA - Tuckey Test).

\section{Results}

Acute toxicity of 2-phenoxyethanol

In the LC50 tests of 96-hour exposure to 2-phenoxyethanol, water temperature, $\mathrm{pH}$ and oxygen saturation ranges were $18.3-19.6^{\circ} \mathrm{C}, 7.48-8.24$, and $69-103 \%$, respectively. Based on 
Table 1

The effect of carp anaesthesia with 2-phenoxyethanol on blood plasma indices

\begin{tabular}{|l|c|c|c|}
\hline Indices & $\begin{array}{l}\text { Control } \\
\mathrm{x} \pm \mathrm{SD}(\mathrm{n}=10)\end{array}$ & $\begin{array}{l}\text { Immediately after } \\
\text { anaesthesia } \\
\mathrm{x} \pm \mathrm{SD}(\mathrm{n}=10)\end{array}$ & $\begin{array}{c}\text { 24 h after anaesthesia } \\
\mathrm{x} \pm \mathrm{SD}(\mathrm{n}=10)\end{array}$ \\
\hline Kortizol $\left(\mu \mathrm{mol} \cdot \mathrm{l}^{-1}\right)$ & $667 \pm 13^{\mathrm{a}}$ & $668 \pm 15^{\mathrm{a}}$ & $670 \pm 21^{\mathrm{a}}$ \\
\hline GLU $\left(\mu \mathrm{mol} \cdot \mathrm{l}^{-1}\right)$ & $5.55 \pm 0.31^{\mathrm{a}}$ & $5.61 \pm 0.28^{\mathrm{a}}$ & $5.8 \pm 0.58^{\mathrm{a}}$ \\
\hline $\mathrm{TP}\left(\mathrm{g} \cdot \mathrm{l}^{-1}\right)$ & $34.4 \pm 0.78^{\mathrm{a}}$ & $34.5 \pm 0.90^{\mathrm{a}}$ & $35.8 \pm 1.48^{\mathrm{a}}$ \\
\hline $\mathrm{NH}_{3}\left(\mu \mathrm{mol} \cdot \mathrm{l}^{-1}\right)$ & $524 \pm 2.03^{\mathrm{a}}$ & $508.3 \pm 2.21^{\mathrm{a}}$ & $501 \pm 1.70^{\mathrm{a}}$ \\
\hline TRIG $\left(\mu \mathrm{mol} \cdot \mathrm{l}^{-1}\right)$ & $0.50 \pm 0.09^{\mathrm{a}}$ & $0.50 \pm 0.10^{\mathrm{a}}$ & $0.47 \pm 0.08^{\mathrm{a}}$ \\
\hline AST $\left(\mu \mathrm{kat} \cdot \mathrm{l}^{-1}\right)$ & $2.04 \pm 0.02^{\mathrm{a}}$ & $2.05 \pm 0.02^{\mathrm{a}}$ & $2.09 \pm 0.03^{\mathrm{a}}$ \\
\hline ALT $\left(\mu \mathrm{kat} \cdot \mathrm{l}^{-1}\right)$ & $0.15 \pm 0.01^{\mathrm{a}}$ & $0.19 \pm 0.01^{\mathrm{a}}$ & $0.35 \pm 0.03^{\mathrm{b}}$ \\
\hline ALP $\left(\mu \mathrm{kat} \cdot \mathrm{l}^{-1}\right)$ & $0.20 \pm 0.02^{\mathrm{a}}$ & $0.21 \pm 0.03^{\mathrm{a}}$ & $0.19 \pm 0.02^{\mathrm{a}}$ \\
\hline CK $\left(\mu \mathrm{kat} \cdot \mathrm{l}^{-1}\right)$ & $162.9 \pm 0.35^{\mathrm{a}}$ & $161.9 \pm 0.72^{\mathrm{a}}$ & $163.1 \pm 0.53^{\mathrm{a}}$ \\
\hline
\end{tabular}

Note: 1 For the determination of $\mathrm{CK}$, blood plasma at 1:12 dilution with physiological saline was used. Groups with different alphabetic superscripts differ significantly at $p<0.05$ (ANOVA).

the results of the tests, lethal concentrations of 2-phenoxyethanol in carp at 96-hour exposure to the anaesthetic are 96hLC50 $0.17 \mathrm{ml} \cdot \mathrm{l}^{-1}$; 96hLC0.1 $0.13 \mathrm{ml} \cdot \mathrm{l}^{-1}$; 96hLC99.9 $0.26 \mathrm{ml} \cdot \mathrm{l}^{-1}$.

A post mortem examination of the fish performed after the acute toxicity tests showed increased presence of aqueous mucous. Gills were dark in colour and bled readily when injured. The body cavity contained excess moisture, and an increased injection of visceral vessels was also observed. These results indicated that the fish became more sensitive to mechanical injury after 2-phenoxyethanol exposure.

In the LC50 tests of 10 minute exposure to 2-phenoxyethanol, water temperature, $\mathrm{pH}$ and oxygen saturation were $20^{\circ} \mathrm{C}, 7.65$, and $95 \%$, respectively. The effect of 2 -phenoxyethanol concentrations on the onset of individual phases of anaesthesia and recovery is shown in Fig. 1. Based on the results of the acute 2-phenoxyethanol toxicity test on carp, lethal concentrations at $10 \mathrm{~min}$ exposure to the anaesthetic are $10 \mathrm{minLC} 500.39 \mathrm{ml} \cdot \mathrm{l}^{-1}$, 10minLC0.1 $0.30 \mathrm{ml} \cdot \mathrm{l}^{-1}$ and 10minLC99.9 $0.50 \mathrm{ml} \cdot \mathrm{l}^{-1}$.

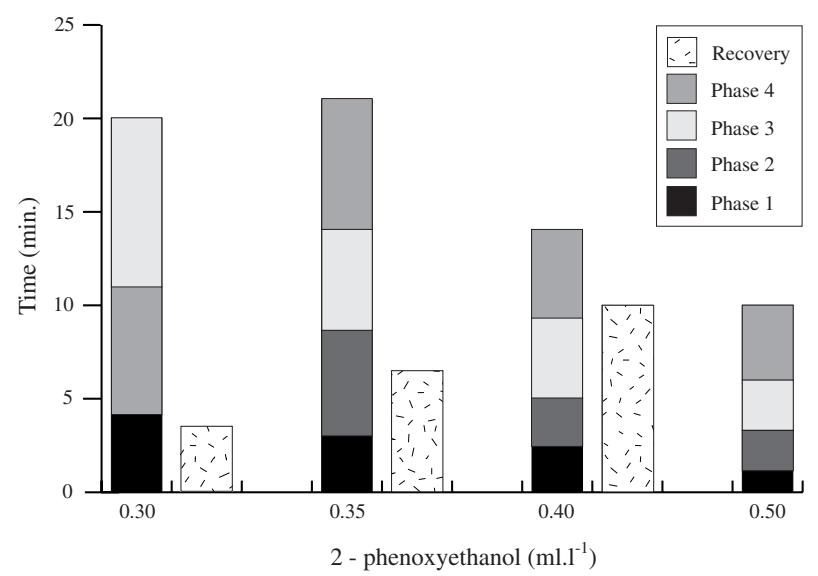

Fig. 1. The effect of 2-phenoxyethanol concentrations on the onset of individual phases of anaesthesia and recovery in carp 
Biochemical profile of blood plasma after exposure to 2-phenoxyethanol

Effects of 2-phenoxyethanol exposure on the biochemical profile of blood plasma in the carp are shown in Table 1 . At $0.30 \mathrm{ml} \cdot \mathrm{l}^{-1}$ concentration of 2-phenoxyethanol and $10 \mathrm{~min}$ exposure, the concentration of alanine aminotrasferase (ALT) increased from $0.15 \pm 0.01$ $\mu \mathrm{kat} \cdot \mathrm{l}^{-1}$ to $0.35 \pm 0.03 \mu \mathrm{kat} \cdot \mathrm{l}^{-1}$ within $24 \mathrm{~h}$ post anaesthesia. The difference is significant at $p<0.05$ level. Other indices (cortisol, GLU, TP, TRIG, $\mathrm{NH}_{3}, \mathrm{ALP}, \mathrm{AST}, \mathrm{CK}$ ) did not differ significantly among the groups.

\section{Discussion}

The 96LC50 value of $0.17 \mathrm{ml} \cdot \mathrm{l}^{-1}$ ranks 2-phenoxyethanol among relatively harmless substances. In our experiments, fish were exposed to the anaesthetic for $10 \mathrm{~min}$ only. The 10 minLC50 value in carp was roughly two times higher than the 96hLC50 value. The therapeutic index (i.e. the ratio between the therapeutic and the lethal concentration) was, however, very low (0.39: 0.30). Although the $10 \mathrm{minLC} 0.1$ value found in the present study $\left(0.30 \mathrm{ml} \cdot \mathrm{l}^{-1}\right)$ is higher than the recommended concentration for anaesthesia purposes, it is important that procedures recommended for the administration of the anaesthetic be adhered to meticulously in order to prevent injury to anaesthetized carp. The sensitivity to anaesthetics is generally affected by the health and physical condition of the fish. It may also be affected by oxygen concentrations: an oxygen deficiency increases the effectiveness of anaesthetics (Svobodová et al. 1987).

The most important factor affecting the efficiency of 2-phenoxyethanol for fish, however, is water temperature: the higher the temperature, the higher the efficiency of the anaesthetic for fish. Repeated use of 2-phenoxyethanol increases the tolerance of the fish to the anaesthetic (Weyl et al. 1996).

Because young fish are more sensitive to 2-phenoxyethanol than old fish, lower concentrations of the anaesthetic should be used for the former, as they provide much wider safety anaesthesia margins (Barton and Helfrich 1981).

It follows from Fig. 1 that the onset of individual phases of anaesthesia and recovery times depended on 2-phenoxyethanol concentrations used. At the $0.50 \mathrm{ml} \cdot \mathrm{l}^{-1}$ concentration, Phase 4 began 10 min after the administration of the anaesthetic and was followed by the death of the fish. The same effect of anaesthetic concentration on to the onset of anaesthesia was described by Myszkowski et al. (2002) and Weyl et al. (1996).

In the study of the carp, lower 2-phenoxyethanol concentrations of 96hLC50 $(0.1 ; 99.9)$ and 10minLC50 $(0.1 ; 99.9)$ were found than in the study with rainbow trout (Velíšek and Svobodová 2004), although the two studies were performed under identical conditions with the exception of water temperature. It might be hypothesized that toxicity of an anaesthetic administered to carp at artificial spawning or when providing veterinary care at temperatures above $20^{\circ} \mathrm{C}$ may be even slightly higher.

The biochemical profile of blood may be a source of important information on the organism's internal environment (Masopust 2000). Anaesthetizing carp with 2-phenoxyethanol at $0.30 \mathrm{ml} \cdot \mathrm{l}^{-1}$ had no effect on the values of stress factors (cortisol, glucose) in blood plasma. Hseu et al. (2000), however, described increased cortisol concentrations during anaesthesia of sea bass with 2-phenoxyethanol at a concentration of $400 \mathrm{ppm}$.

With the exception of ALT, no other biochemical indices examined (TP, TRIG, $\mathrm{NH}_{3}$, ALP, AST, CK) showed any significant differences between carp before and after anaesthesia. Increased levels of blood plasma ALT in carp $24 \mathrm{~h}$ post anaesthesia with 2-phenoxyethanol at a concentration of $0.30 \mathrm{ml} \cdot \mathrm{l}^{-1}$ testify to parenchymatous tissue damage.

To our knowledge, no other data on biochemical blood profile in carp anaesthetized with 2-phenoxyethanol are available in literature. In a study of rainbow trout anaesthetized with 
$0.30 \mathrm{ml} \cdot \mathrm{l}^{-1}$ 2-phenoxyethanol, however, no significant negative effects of anaesthesia on parenchymatous tissues were found (Velíšek and S vobodová 2004a).

Adámek et al. (1993) studied effects of different concentrations of 2-phenoxyethanol on haematological parameters of carp fry, and found a decrease in blood $\mathrm{pH}$ at the $0.25 \mathrm{ml} \cdot \mathrm{l}^{-1}$, and an increase in erythrocyte and haemoglobin levels at the $0.56 \mathrm{ml} \cdot \mathrm{1}^{-1}$ concentration of 2phenoxyethanol anaesthesia.

McCartes (1992) reported no negative effects of anaesthesia with $0.20 \mathrm{ml} \cdot \mathrm{l}^{-1}$ 2-phenoxyethanol on spermatozoa and their motility in grass carp (Ctenopharyngodon idella) and silver carp (Hypophthalmichthys molitrix).

The 2-phenoxyethanol concentration recommended by the authors for carp broodstock anaesthesia is $0.30 \mathrm{ml} \cdot 1^{-1}$, which has also been recommended by Kaiser and Vine (1998) for silver crucian carp.

When 2-phenoxyethanol is used, it is necessary to strictly observe safety regulations because 2-phenoxyethanol is toxic and dangerous for humans, and in poorly ventilated rooms, it may cause fatigue and drowsiness (S voboda and Kolářová 1999).

\section{Anestezie kapra obecného (Cyprinus carpio L.) 2-phenoxyethanolem: akutní toxicita a vliv na biochemický profil krve}

Cílem práce bylo posoudit akutní toxicitu a pomocí hodnot biochemického profilu krve zhodnotit změny ve tkáních kapra obecného po působení anestetika 2-phenoxyethanol. Ke stanovení akutní toxicity byla použita metoda OECD 203 „Test akutní toxicity na rybách“. Zjištěné hodnoty akutní toxicity 2-phenoxyethanolu pro plůdek kapra obecného byly následující 10minLC50 0.39; 10minLC0.1 0.30; 10minLC99.9 $0.50 \mathrm{ml} . \cdot^{-1}$; 96hLC50 0.17; 96hLC0.1 0.13; 96hLC99.9 $0.26 \mathrm{ml} \cdot \mathrm{l}^{-1}$.

Stanovení změn biochemického profilu krve bylo provedeno vyšetřením krevní plazmy na analyzátoru VETTEST 8008 firmy Medisoft. Biochemický profil krve byl hodnocen u násady kapra obecného před, ihned po 10minutové anestézii a 24 hodin po anestézii v koncentraci $0.30 \mathrm{ml} \cdot \mathrm{l}^{-1}$ 2-phenoxyethanolu. Celkem bylo vyšetřeno 30 kusů ryb $\mathrm{K}_{2}$. Významné zvýšení alanin aminotransferázy (ALT) v krevní plazmě bylo zaznamenáno 24 hodin po anestézii $\mathrm{z}$ hodnoty $0.15 \mu \mathrm{kat} \cdot \mathrm{l}^{-1}$ na $0.35 \mu \mathrm{kat} \cdot \mathrm{l}^{-1}(p<0.05)$. U ostatních sledovaných ukazatelů [(kortizol, glukóza (GLU), celkové bílkoviny (TP), triglyceridy (TRIG), amoniak $\left(\mathrm{NH}_{3}\right)$, alkalická fosfatáza (ALP), aspartát aminotransferáza (AST), kreatinkináza $(\mathrm{CK})]$ nebyly zjištěny rozdíly mezi posuzovanými skupinami.

Výsledky ukázaly, že 2-phenoxyethanol v koncentraci $0.30 \mathrm{ml} \cdot \mathrm{l}^{-1}$ pro plůdek a dvouletéto kapra obecného není zcela bezpečná. Vzhledem k diskutované rozdílné věkové citlivosti předpokládáme bezpečnost této koncentrace pro generační kapry.

\section{Acknowledgement}

This study was supported by project NAZV GF3029 Harmonization with EU in application of principles of pharmacovigilancy in aquaculture in the Czech Republic and project MSM 126100003.

\section{References}

ADÁMEK, Z, FAŠIC, K, PAUL, K, LAMAŠIC, M 1993: The effect of 2-phenoxyethanol narcosis on blood of young carp (Cyprinus carpio L.). Vet Archiv 63: 245-250

BARTON, BA, HELFRICH, H 1981: Time-dose responses of juvenile common carp to 2-phenoxyethanol. Prog Fish Cult 43: 223-231

BROŽOVÁ, V, SVOBODOVÁ, Z 1986: Anaesthetics for fish. Bull VÚRH Vodňany 20: 36-40 (In Czech)

BROWN, LA 1988: Tropical fish medicine. Anaesthesia in fish. Vet Clin Nort Am Small Anim Prac 18: $317-330$

HSEU, JR, CHU, YT, YEH, SL, TING, YY 2002: Application of 2-phenoxyethanol in live transportation of sea bass, Latest calcarifer. J Fish Soc Taiwan 27: 23-48

KAISE, H, VINE, N 1998: The effect of 2-phenoxyethanol and transport packing density on the post-transport survival rate and metabolic activity in the goldfish, Carassius auratus. Aquarium Science and Conservation 2: 1-7 
MASOPUST, J 2000: Clinical biochemistry. Karolinum Praha. 832 p. (In Czech)

McCARTER, N 1992: Sedation of grass carp and silver carp with 2-phenoxyethanol during spawning. Progres Fish Cult 54: 263-265

MYSZKOWSKI, L, KAMINSKI, R, WOLNICKI, J 2002: Respose of juvenile tench Tinca tinca (L.) to 2-phenoxyethanol. J Fish Biol 23: 400-430

ROSS, LG, ROSS B 1999: Anaesthetic and sedative techniques for aquatic animals. Second Edition, Oxford, Blackwell Science Ltd. 159 p.

SVOBODA, M, KOLÁŘOVÁ, J 1999: A survey of anaesthetics used in the fish farming. Health protection of fish proceeding of papers. VÚRH JU Vodňany pp 49-72 (In Czech)

SVOBODOVÁ, Z, PRAVDA, D, PALÁČKOVÁ, J 1986: Unified methods of haematological examination of fish. Research Institute of Fish Culture and Hydrobiology, Vodňany, Methods No. 20, 31 p.

SVOBODOVÁ, Z, GELNEROVÁ, J, JUSTÝN, J, KRAUPER, V, MÁCHOVÁ, J, SIMANOV, L, VALENTOVÁ, O, VYKUSOVÁ, B, WOHLGEMUTH, E 1987: Toxicology of aquatic animals. SZN Praha 231 p. (In Czech)

THEINPOINT, D, NIEMEGEERS, CJE 1965: R 7464- a new potent anaesthetic in fish. International Zoo Yearbook 5: 202-205

VELÍŠEK, J, SVOBODOVÁ,Z 2004a: Anaesthesia of rainbow trout (Oncorhynchus mykiss) with 2-phenoxyethanol: acute toxicity and effects on biochemical blood profile. Acta Vet Brno 73: in press

WEYL, O, KAISER, H, HECHT, T 1996: On efficacy and mode of 2-phenoxyethanol as an anesthetic for gold fish, Carassius auratus (L.), at different temperatures and concentrations. Aquaculture Res 27: 757-764 